\title{
CORROSION RESISTANCE IMPROVEMENT OF TITANIUM BASE ALLOYS
}

\author{
Mihai V. Popa, Ecaterina Vasilescu*, Paula Drob, Cora Vasilescu and Silviu I. Drob \\ Institute of Physical Chemistry "Ilie Murgulescu", Spl. Independentei 202, 060021 Bucharest, Romania \\ Daniel Mareci \\ Technical University “Gh. Asachi”, Bd. Mangeron 71, 700050 Iasi, Romania \\ Julia C. Mirza Rosca \\ Las Palmas de Gran Canaria University, Mechanical Engineering Department, Despacho 11, 35017 Tafira, Spain
}

Recebido em 4/2/10; aceito em 2/6/10; publicado na web em 24/8/10

\begin{abstract}
The corrosion resistance of the new Ti-6Al-4V-1Zr alloy in comparison with ternary Ti-6Al-4V alloy in Ringer-Brown solution and artificial Carter-Brugirard saliva of different $\mathrm{pH}$ values was studied. In Ringer-Brown solution, the new alloy presented an improvement of all electrochemical parameters due to the alloying with $\mathrm{Zr}$; also, impedance spectra revealed better protective properties of its passive layer. In Carter-Brugirard artificial saliva, an increase of the passive film thickness was proved. Fluoride ions had a slight negative influence on the corrosion and ion release rates, without to affect the very good stability of the new Ti-6Al-4V-1Zr alloy.
\end{abstract}

Keywords: corrosion rates; EIS; Ti6A14V1Zr alloy.

\section{INTRODUCTION}

Titanium and its Ti-6Al-4V alloy were used as implant material for many years. ${ }^{1-6}$ These materials have very good corrosion resistance and biocompatibility. In the last years, important problems have been raised over their long-term performance. Several cases of extensive metallosis and necrosis in periprosthetic tissues of failed cemented Ti-6Al-4V prostheses were registered. ${ }^{7,8}$ In recent years, attempts were made to develop titanium alloys with biomechanical compatibility, low modulus and biochemical compatibility by the using of non-toxic alloying elements as: $\mathrm{Ti}, \mathrm{Nb}, \mathrm{Zr}^{9-11}$ These elements are chemically very stable and highly corrosion resistant in biological fluids and are considered immune for human body. ${ }^{12,13}$

Zirconium has excellent corrosion resistance to many types of corrosive media including strong acids and basses. Zirconium has acceptable mechanical strength and good biocompatibility. ${ }^{14,15}$ Zirconium implants exhibit good osseointegration and the degree of bone-implant contact is higher for $\mathrm{Zr}$ than for Ti. ${ }^{16-19}$ Only few alloys with zirconium were elaborated for implant use: Ti-2.2Al-2.6Zr, ${ }^{11}$ Ti-13Nb-13Zr, ${ }^{20,21}$ Ti-15Zr-4Nb-4Ta, ${ }^{10}$ Ti-15Zr-4Nb-4Ta-0.2Pd, ${ }^{22}$ Ti-50Zr and $\mathrm{Zr}-25 \mathrm{Nb} .{ }^{14}$

The new Romanian Ti-6Al-4V-1Zr alloy was elaborated for to combine the very good mechanical properties of Ti-6Al-4V alloy with the good biocompatibility of zirconium. Its corrosion resistance in Ringer-Brown solution and Carter-Brugirard artificial saliva of different $\mathrm{pH}$ values was studied in this paper.

\section{EXPERIMENTAL}

The alloy synthesis was performed by melting in vacuum. The obtained composition for main constituents in wt $\%$ is: $\mathrm{Al}-6.12$; V $-3.92 ; \mathrm{Zr}-1.07$; balance $-\mathrm{Ti}$. The electrodes for experiments were prepared from ingots in casting state.

All measurements were carried out in Ringer-Brown solution and artificial Carter-Brugirard saliva at $37 \pm 1^{\circ} \mathrm{C}$. Ringer-Brown solution of $\mathrm{pH}=7.0$ had the following composition (g/L): $\mathrm{NaCl}-6 ; \mathrm{KCl}-0.4$; $\mathrm{CaCl}_{2} .2 \mathrm{H}_{2} \mathrm{O}-0.2$; natrium lactate $-3.05 ; \mathrm{pH}=7$. Carter-Brugirard

\footnotetext{
*e-mail: ec_vasilescu@yahoo.com
}

saliva of $\mathrm{pH}=2.54 ; 5.52 ; 8.21 ; 8.91$ had the following composition (g/L): $\mathrm{KCl}-1.2 ; \mathrm{NaCl}-0.7 ; \mathrm{KH}_{2} \mathrm{PO}_{4}-0.26 ; \mathrm{KSCN}-0.33 ; \mathrm{Na}_{2} \mathrm{HPO}_{4}$ -0.19 ; urea -0.13 ; $\mathrm{NaHCO}_{3}-1.5$; neutral saliva was doped with $0.05 \mathrm{M} \mathrm{NaF}$ for to reproduce the $\mathrm{F}^{-}$concentration from the dental hygiene products.

The following experimental techniques were used: potentiodynamic and linear polarization, electrochemical impedance spectroscopy (EIS) and monitoring of the open circuit potentials, $\mathrm{E}_{\mathrm{oc}}$ and of the open circuit potential gradients, due to the $\mathrm{pH}, \Delta \mathrm{E}_{\mathrm{oc}}(\mathrm{pH})$ and content, $\Delta \mathrm{E}_{\mathrm{oc}}(\mathrm{c})$ non-uniformities of the artificial Carter-Brugirard saliva, versus exposure time $(3000 \mathrm{~h})$.

The cyclic potentiodynamic polarization was applied beginning from -0.5 to $+4.0 \mathrm{~V}$ (vs. SCE) using a scan rate of $10 \mathrm{mV} / \mathrm{sec}$. Voltalab 80 equipment with its VoltaMaster 4 program were used. From the voltammograms, the main electrochemical parameters were determined: $\mathrm{E}_{\text {corr }}$ - corrosion potential, like zero current potential, $\mathrm{E}_{\mathrm{p}}$ - passivation potential at which the current density is constant; $\left|\mathrm{E}_{\text {corr }}-\mathrm{E}_{\mathrm{p}}\right|$ difference represents the tendency to passivation (low values characterise a good, easy passivation); $\Delta \mathrm{E}_{\mathrm{p}}$ - passive potential range of the constant current; $i_{p}$ - passive current density.

The linear polarization measurements (Tafel) were carried out for a range of $\pm 200 \mathrm{mV}$ around the open circuit potential, with a scan rate of $10 \mathrm{mV} / \mathrm{sec}$. The same Voltalab 80 equipment with its VoltaMaster 4 program that delivered the values of the corrosion current densities $\left(\mathrm{i}_{\text {corr }}\right)$ and rates $\left(\mathrm{V}_{\text {corr }}\right)$ obtained from Tafel curves was used.

The total quantity of the ions $\left(\mathrm{ng} / \mathrm{cm}^{2}\right)$ released in the solution was determined:

$$
\text { ion release rate }=1.016 . \mathrm{V}_{\text {corr }} \cdot 10^{5}
$$

where: $\mathrm{V}_{\text {corr }}=$ corrosion rate in $\mathrm{mm} /$ year.

The electrochemical impedance spectroscopy (EIS) was performed at open circuit potential $\left(\mathrm{E}_{\mathrm{oc}}\right)$ and at $+0.4 \mathrm{~V}$ (a potential from passive domain) using a PAR $263 \mathrm{~A}$ potentiostat connected with a PAR 5210 lock-in amplifier. The amplitude of the AC potential was $10 \mathrm{mV}$ and single sine wave measurements at frequencies between $10^{-1}$ and $10^{5} \mathrm{~Hz}$ were performed.

The open circuit potentials $\mathrm{E}_{\mathrm{oc}}$ were registered with the exposure time (3000 h till present) using a performing Hewlett-Packard 
multimeter. Three potential gradients due to the $\mathrm{pH}$ non-uniformity, $\Delta \mathrm{E}_{\mathrm{oc}}(\mathrm{pH})$ of Carter-Brugirard saliva (relations 2-4) and one potential gradient (relation 5) due to the composition non-uniformity, $\Delta \mathrm{E}_{\mathrm{oc}}(\mathrm{c})$ of Carter-Brugirard saliva were monitored:

$$
\begin{gathered}
\Delta E_{o c 1}(p H)=E_{o c}^{p H=2.54}-E_{o c}^{p H=5.52} \\
\Delta E_{o c 2}(p H)=E_{o c}^{p H=2.54}-E_{o c}^{p H=8.21} \\
\Delta E_{o c 3}(p H)=E_{o c}^{p H=5.52}-E_{o c}^{p H=8.21} \\
\Delta E_{o c 4}(c)=E_{o c}^{p H=8.21}-E_{o c}^{N a F}
\end{gathered}
$$

\section{RESULTS AND DISCUSSION}

\section{Improvement of corrosion resistance in Ringer-Brown solution}

\section{Improvement of corrosion resistance from polarization curves}

Potentiodynamic polarization curves for the new Ti-6Al-4V$1 \mathrm{Zr}$ alloy exhibited self-passivation, stable, very constant passive current density and a corrosion potential placed in the passive potential range of $\mathrm{Ti}, \mathrm{Al}, \mathrm{V}, \mathrm{Zr}$ on the Pourbaix ${ }^{23}$ diagrams. Comparing with Ti-6Al-4V alloy (Table 1) it results an improvement of all electrochemical parameters, due to the favorable influence of zirconium.

Table 1. Main electrochemical parameters in Ringer-Brown solution

\begin{tabular}{lccccc}
\hline Alloy & $\begin{array}{c}\mathrm{E}_{\text {corr }} \\
(\mathrm{V})\end{array}$ & $\begin{array}{c}\mathrm{E}_{\mathrm{p}} \\
(\mathrm{V})\end{array}$ & $\begin{array}{c}\left|\mathrm{E}_{\text {corr }}-\mathrm{E}_{\mathrm{p}}\right| \\
(\mathrm{V})\end{array}$ & $\begin{array}{c}\Delta \mathrm{E}_{\mathrm{p}} \\
(\mathrm{V})\end{array}$ & $\begin{array}{c}\mathrm{i}_{\mathrm{p}} \\
\left(\mu \mathrm{A} / \mathrm{cm}^{2}\right)\end{array}$ \\
\hline Ti6A14V & -0.560 & +0.100 & 0.660 & $>4$ & 14 \\
Ti6A14V1Zr & -0.403 & -0.100 & 0.300 & $>4$ & 1.5 \\
\hline
\end{tabular}

The alloy with $\mathrm{Zr}$ exhibited more electropositive corrosion potentials than the comparison Ti-6A-14V alloy due to the galvanic couple effect of zirconium. The tendency to passivation $\left|\mathrm{E}_{\text {corr }}-\mathrm{E}_{\mathrm{p}}\right|$ is lower (better) for Ti-6Al-4V-1Zr alloy showing that, this alloy can be easier passivated as result of the favorable influence of $\mathrm{Zr}$ that participates with its passive oxide $\left(\mathrm{ZrO}_{2}\right)^{10,22}$ to the formation of the passive film. This layer is more compact, more stable than of the comparison alloy, as it results from the lower values of the passive current densities, $i_{p}$.

Also, the corrosion current density, corrosion and ion release rates (Table 2) presented lower values for Ti-6Al-4V-1Zr alloy than for Ti-6Al-4V alloy showing the benefic influence of $\mathrm{Zr}$.

\section{Improvement of corrosion resistance from electrochemical impedance spectra}

The behavior of the new Ti-6Al-4V-1Zr alloy was studied from Bode spectra that permit to determine the presence of a compact passive film if the phase angle is close to $-90^{\circ}$ over wide frequency range of the spectrum, if the Bode form of $\log \mathrm{Zmod}-\log \mathrm{f}$ has a linear portion with the slope about -1 at intermediate frequency and if the parameter $\mathrm{n}$ is about $1.24,25$

Table 2. Corrosion current density, corrosion and ion release rates in RingerBrown solution

\begin{tabular}{lccccc}
\hline Alloy & $\begin{array}{c}\mathrm{R}_{\mathrm{p}} \\
\left(\mathrm{k} \Omega / \mathrm{cm}^{2}\right)\end{array}$ & $\begin{array}{c}\mathrm{i}_{\text {corr }} \\
\left(\mu \mathrm{A} / \mathrm{cm}^{2}\right)\end{array}$ & $\begin{array}{c}\mathrm{V}_{\text {corr }} \\
(\mu \mathrm{m} / \mathrm{yr} .)\end{array}$ & $\begin{array}{c}\text { Resistance } \\
\text { class }\end{array}$ & $\begin{array}{c}\text { Ion release rate } \\
\left(\mathrm{ng} / \mathrm{cm}^{2}\right)\end{array}$ \\
\hline Ti6A14V & 42.13 & 0.82 & 7.13 & Very Stable & 724.41 \\
Ti6Al4V1Zr & 65.19 & 0.42 & 3.65 & Very Stable & 370.84 \\
\hline
\end{tabular}

In Figure 1, the Bode spectrum obtained for the new quaternary Ti-6Al-4V-1Zr alloy at open circuit potential exhibited a phase angle of $\approx-80^{\circ}$ and a linear portion with a slope $\approx-1$. Similar results obtained S. Piazza et al. $;^{26}$ an electric equivalent circuit with two time constants (Figure 2) was modeled: one constant is for the inner, thin, barrier, compact, passive film illustrated by the compact layer resistance, $\mathrm{R}_{1}$ and capacitance $\mathrm{CPE}_{1}$ (a constant phase element to describe the deviation from an ideal capacitor due to the certain heterogeneity of the surface) $; 25$ the second time constant is for the outer, porous layer and is represented by the porous layer resistance, $R_{2}$ and capacitance $C P E_{2}$.

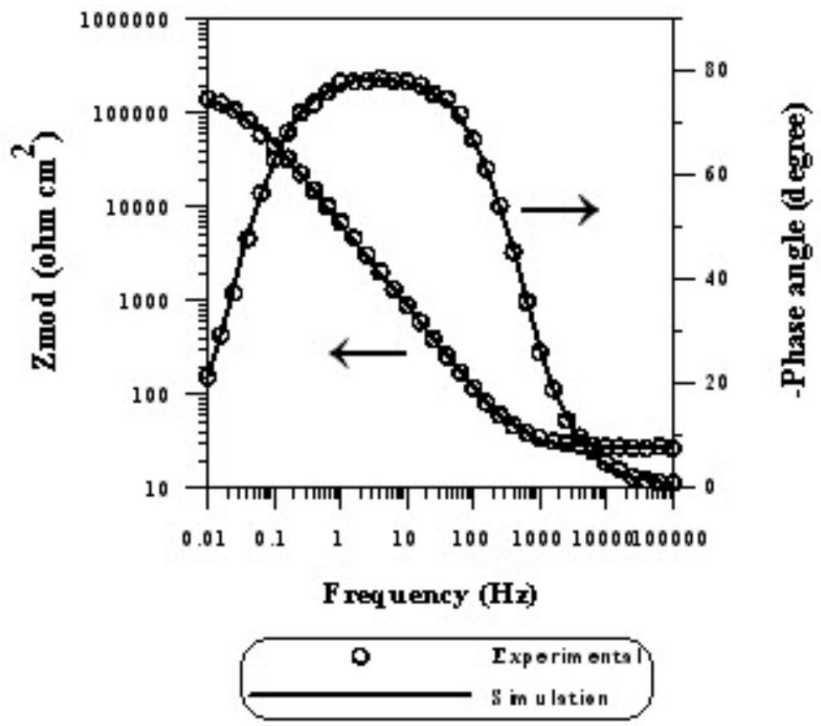

Figure 1. Bode spectra in Ringer-Brown solution at open circuit potential for Ti-6Al-4V-1Zr alloy

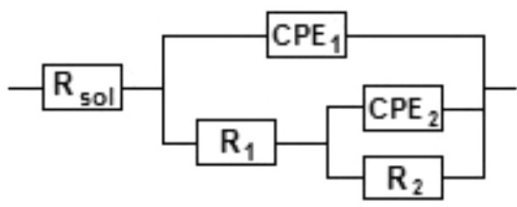

Figure 2. Electric equivalent circuit with two time constants

For ternary Ti-6Al-4V alloy, Bode plot (Figure 3) at $\mathrm{E}_{\mathrm{oc}}$ exhibited two phase angles at $-70^{\circ}$ and $-80^{\circ}$ corresponding with three time constants: the third time constant is for diffusion processes through

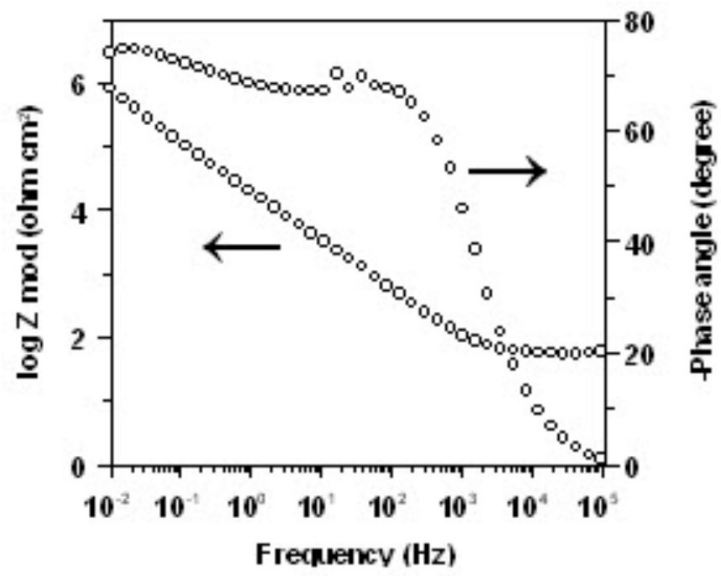

Figure 3. Bode spectra in Ringer-Brown solution at open circuit potential for Ti-6Al-4V alloy 
Table 3. Parameters for equivalent electric circuit at $\mathrm{E}_{\mathrm{oc}}$

\begin{tabular}{|c|c|c|c|c|c|c|c|c|c|c|}
\hline Potential & Alloy & $\begin{array}{c}\mathrm{R}_{1} \\
\left(\Omega \mathrm{cm}^{2}\right)\end{array}$ & $\begin{array}{c}\mathrm{CPE}_{1} \\
\left(\mathrm{~S} \mathrm{~s}^{\mathrm{n}} \mathrm{cm}^{-2}\right)\end{array}$ & $\mathrm{n}_{1}$ & $\begin{array}{c}\mathrm{R}_{2} \\
\left(\Omega \mathrm{cm}^{2}\right)\end{array}$ & $\begin{array}{c}\mathrm{CPE}_{2} \\
\left(\mathrm{~S} \mathrm{~s}^{\mathrm{n}} \mathrm{cm}^{-2}\right)\end{array}$ & $\mathrm{n}_{2}$ & $\begin{array}{c}\mathrm{R}_{3} \\
\left(\Omega \mathrm{cm}^{2}\right)\end{array}$ & $\begin{array}{c}\mathrm{W} \\
\left(\mathrm{S} \mathrm{s}^{\mathrm{n}} \mathrm{cm}^{-2}\right)\end{array}$ & $\mathrm{n}_{3}$ \\
\hline \multirow{2}{*}{$\overline{\mathrm{E}_{\mathrm{oc}}}$} & Ti6Al4V & $9.2 \times 10^{4}$ & $2.3 \times 10^{-5}$ & 0.87 & $1.7 \times 10^{3}$ & $6.1 \times 10^{-5}$ & 0.84 & $6.8 \times 10^{2}$ & $2.1 \times 10^{-4}$ & 0.51 \\
\hline & Ti6Al4V1Zr & $1.6 \times 10^{5}$ & $2.9 \times 10^{-6}$ & 0.98 & $5.3 \times 10^{3}$ & $3.1 \times 10^{-5}$ & 0.91 & - & - & - \\
\hline \multirow[t]{2}{*}{$+0.4 \mathrm{~V}$} & Ti6Al4V & $9.3 \times 10^{5}$ & $1.3 \times 10^{-6}$ & 0.89 & - & - & - & - & - & - \\
\hline & Ti6Al4V1Zr & $7.9 \times 10^{6}$ & $1.1 \times 10^{-6}$ & 0.99 & - & - & - & - & - & - \\
\hline
\end{tabular}

the passive film ${ }^{27}$ and is shown by the diffusion Warburg impedance, $\mathrm{W}$ and diffusion resistance $\mathrm{R}_{3}$ (Figure 4).

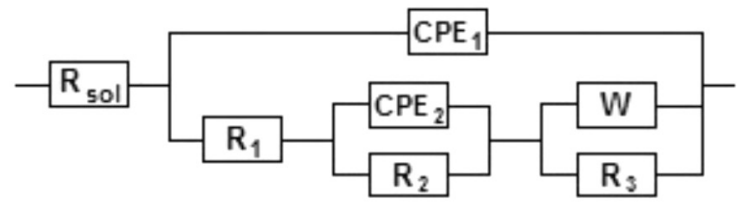

Figure 4. Electric equivalent circuit with three time constants

Fitting parameters for Ti-6Al-4V-1Zr alloy (Table 3) show that the resistance of the porous layer, $R_{2}$ is lower than the resistance of the barrier layer, $\mathrm{R}_{1}$, denoting a more protective barrier layer. ${ }^{28} \mathrm{Capa}-$ citance of the porous layer, $\mathrm{CPE}_{2}$ is higher than the capacitance of the barrier layer, $\mathrm{CPE}_{1}$ supporting the idea that the corrosion resistance is mainly due to the barrier layer.

Higher value of resistance $\mathrm{R}_{1}$ of the quaternary Ti-6Al-4V-1Zr alloy than of the ternary Ti-6Al-4V alloy were registered; this fact denotes better protective properties of the passive layer on the new Ti-6Al-4V-1Zr alloy. The frequency independent parameter $n_{3}=$ 0.51 for ternary Ti-6Al-4V alloy indicates diffusion processes; the diffusion resistance $R_{3}$ has lower value than $R_{1}$ or $R_{2}$, showing reduced diffusion processes through the passive layer.

In the passive potential range, at $+0.4 \mathrm{~V}$, Bode spectra both for Ti$6 \mathrm{Al}-4 \mathrm{~V}-1 \mathrm{Zr}$ and Ti-6Al-4V alloys (Figure 5) presented a phase angle of $\approx-80^{\circ}$ over the wide frequency range, a slope of -1 and $n_{1} \approx 0.90$, showing the same passive, compact film (Table 3 ). No reactions to this protective layer were detected and the electric equivalent circuit for
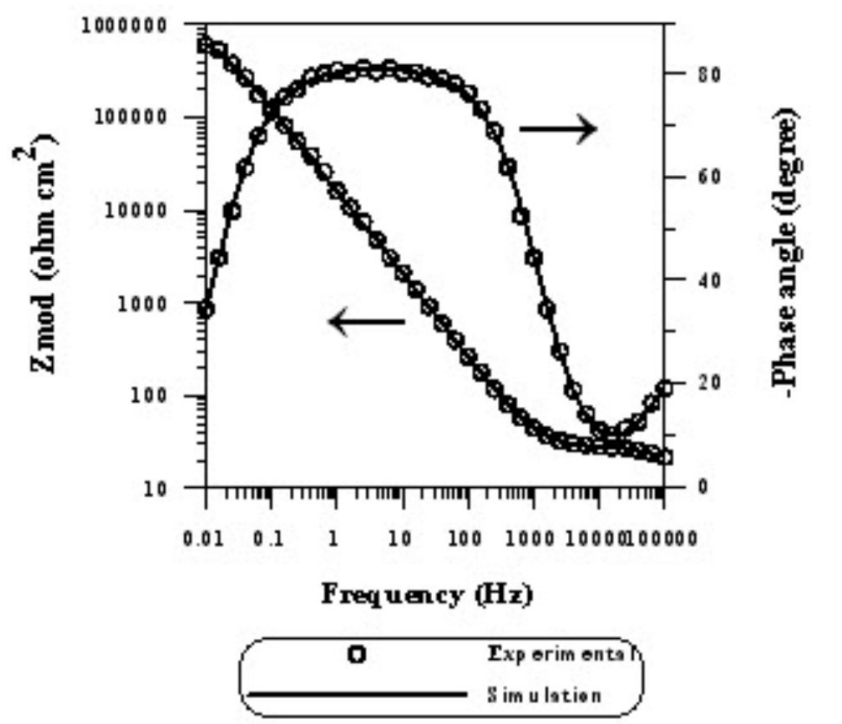

Figure 5. Bode spectra in Ringer-Brown solution at $+0.4 \mathrm{~V}$ for Ti-6Al-4V$1 \mathrm{Zr}$ alloy the fitting of the impedance data contains one time constant (Figure 6).

The EIS data are in agreement with the results obtained from the cyclic polarization curves.

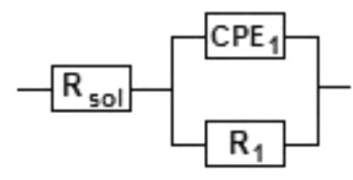

Figure 6. Electric equivalent circuit with one time constant

\section{Improvement of corrosion resistance in artificial Carter-Brugirard saliva}

Improvement of corrosion resistance from polarization curves

In artificial Carter-Brugirard saliva, the new Ti-6Al-4V-1Zr alloy is self-passivated both in acid, neutral and alkaline saliva. The most electropositive corrosion potential and lowest passive current density were registered in neutral saliva of $\mathrm{pH}=8.21$ (Table 4 ) showing that the passive film is the most stable and the alloy has the best resistance in this saliva. The difference between the corrosion potential, $\mathrm{E}_{\mathrm{cor}}$ and passivation potential, $\mathrm{E}_{\mathrm{p}}$ that provide an indication of the ease of passivation has the lowest value in neutral saliva, proving that the best passivation of the alloy appeared in this saliva. ${ }^{29}$ The fluoride ion has a slow negative influence on the electrochemical parameters due its higher corrosivity..$^{24,30,31}$

Table 4. Main electrochemical parameters in Carter-Brugirard saliva

\begin{tabular}{lcccccc}
\hline $\mathrm{pH}$ & Alloy & $\begin{array}{c}\mathrm{E}_{\text {corr }} \\
(\mathrm{V})\end{array}$ & $\begin{array}{c}\mathrm{E}_{\mathrm{p}} \\
(\mathrm{V})\end{array}$ & $\begin{array}{c}\mid \mathrm{E}_{\text {corr }}-\mathrm{E}_{\mathrm{p}} \\
(\mathrm{V})\end{array}$ & $\begin{array}{c}\Delta \mathrm{E}_{\mathrm{p}} \\
(\mathrm{V})\end{array}$ & $\begin{array}{c}\mathrm{i}_{\mathrm{p}} \\
\left(\mu \mathrm{A} / \mathrm{cm}^{2}\right)\end{array}$ \\
\hline 2.54 & Ti6A14V & -0.560 & -0.335 & 0.225 & $>4$ & 2.00 \\
& Ti6A14V1Zr & -0.403 & -0.295 & 0.106 & $>4$ & 1.80 \\
5.52 & Ti6A14V & -0.410 & -0.220 & 0.190 & $>4$ & 1.90 \\
& Ti6Al4V1Zr & -0.320 & -0.210 & 0.110 & $>4$ & 1.65 \\
8.21 & Ti6A14V & -0.300 & -0.190 & 0.110 & $>4$ & 1.90 \\
& Ti6A14V1Zr & -0.280 & -0.180 & 0.100 & $>4$ & 1.32 \\
8.91 & Ti6A14V & -0.540 & -0.420 & 0.140 & $>4$ & 1.80 \\
& Ti6A14V1Zr & -0.520 & -0.400 & 0.120 & $>4$ & 1.60 \\
& Ti6A14V & -0.480 & -0.370 & 0.120 & $>4$ & 1.90 \\
& Ti6A14V1Zr & -0.401 & -0.290 & 0.111 & $>4$ & 1.75 \\
\hline
\end{tabular}

In comparison with Ti-6Al-4V alloy, from Table 4 it resulted more favorable values of all electrochemical parameters for Ti-6Al-4V-1Zr alloy, revealing the beneficial effect of $\mathrm{Zr}$.

\section{Improvement of corrosion resistance from in time variations of the} open circuit potentials

From Figure 7 it can be seen that the open circuit potential values of the new quaternary alloy have shown an overall increase for about 

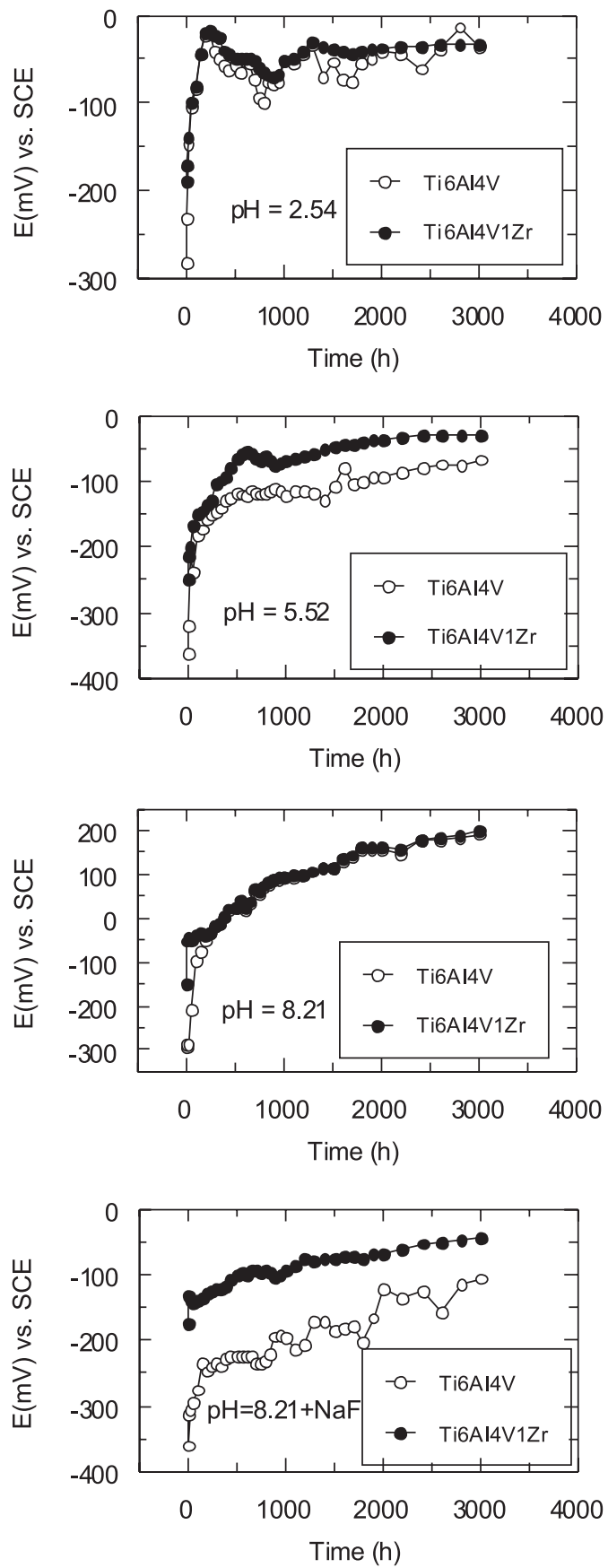

Figure 7. In time variations of open circuit potential in artificial CarterBrugirard saliva

500 immersion hours and than slowly tended to more electropositive values; for Carter-Brugirard saliva of $\mathrm{pH}=2.54$, the open circuit potential values tended to a constant level after 500 immersion hours. According to Blackwood, ${ }^{32}$ the shift of $\mathrm{E}_{\mathrm{oc}}$ to positive values shows an increase of the passive film thickness and correspondingly, a decrease of the corrosion rate. Therefore, the new Ti-6Al-4V-1Zr alloy improved its passive state and corrosion resistance.

The more electronegative values of $\mathrm{E}_{\mathrm{oc}}$ registered at $\mathrm{pH}=2.54$ are due to the fact that, at this $\mathrm{pH}$ value, only $\mathrm{Ti}$ is in the passive state on the Pourbaix diagrams, ${ }^{23}$ while $\mathrm{Al}, \mathrm{V}$ and $\mathrm{Zr}$ are placed in the active state and so, some dissolution and repassivation processes take place, conducting to the variations of $\mathrm{E}_{\mathrm{oc}}$ for about 500 exposure hours.

At $\mathrm{pH}=5.52$, only $\mathrm{V}$ is in the corrosion state, $\mathrm{Ti}, \mathrm{Al}$ and $\mathrm{Zr}$ are passive; so, a more stable values of the open circuit potentials can be observed because of more compact passive layer that contains the resistant $\mathrm{Al}_{2} \mathrm{O}_{3}$ and $\mathrm{ZrO}_{2}$ oxides. ${ }^{10,22}$

In neutral saliva of $\mathrm{pH}=8.21$, the open circuit potentials of Ti$6 \mathrm{Al}-4 \mathrm{~V}-1 \mathrm{Zr}$ alloy stabilized at very electropositive values (about +0.2 V) after 3000 immersion hours, showing a very resistant, compact passive layer; at this $\mathrm{pH}$ value, all constituent elements ( $\mathrm{Ti}, \mathrm{Al}, \mathrm{V}, \mathrm{Zr}$ ) are placed in the passivation state on the Pourbaix diagrams, ${ }^{23}$ contributing with their insoluble oxides to the formation of the passive layer.

Ternary Ti-6Al-4V alloy presented some oscillations of $\mathrm{E}_{\mathrm{oc}}$ values (Figure 7) suggesting some dissolution and repassivation processes of the passive layer. ${ }^{29,32-34}$ Also, all $\mathrm{E}_{\text {oc }}$ values of ternary Ti-6Al-4V alloy have more electronegative values than of quaternary Ti-6Al-4V-1Zr alloy, pointing out a more stable passive state for the new alloy, due to the passive $\mathrm{ZrO}_{2}$ oxide ${ }^{10,22}$ that is presented in the passive layer.

In the presence of fluoride ions, open circuit potential changed to more electronegative values due to the negative effect of $\mathrm{F}^{-}$ion; ${ }^{24,30,35}$ the same tendency to stabilize and to ennoble was registered, showing a good, resistant passive layer.

Improvement of corrosion resistance from in time variations of the open circuit potential gradients

From Table 5 can be observed that, till present (3000 exposure hours), the open circuit potential gradients have low values (between 0.001 and $0.228 \mathrm{~V}$ ) which cannot generate galvanic or local corrosion; because only differences of $0.6-0.7 \mathrm{~V}$ can initiate and keep galvanic cells. $^{24,27}$

Table 5. Open circuit potential gradients in Carter-Brugirard saliva

\begin{tabular}{llllll}
\hline $\begin{array}{l}\text { Time } \\
(\mathrm{h})\end{array}$ & Alloy & $\begin{array}{l}\Delta \mathrm{E}_{\text {oc1 }} \\
(\mathrm{V})\end{array}$ & $\begin{array}{l}\Delta \mathrm{E}_{\text {oc2 }} \\
(\mathrm{V})\end{array}$ & $\begin{array}{l}\Delta \mathrm{E}_{\text {oc3 }} \\
(\mathrm{V})\end{array}$ & $\begin{array}{l}\Delta \mathrm{E}_{\text {oc4 }} \\
(\mathrm{V})\end{array}$ \\
\hline 100 & Ti6A14V & +0.112 & +0.042 & -0.070 & +0.058 \\
& Ti6A14V1Zr & +0.085 & -0.060 & +0.085 & -0.095 \\
500 & Ti6A14V & +0.038 & +0.075 & -0.017 & +0.053 \\
& Ti6A14V1Zr & +0.045 & -0.013 & +0.048 & -0.101 \\
1000 & Ti6A14V & +0.164 & +0.146 & -0.018 & +0.044 \\
& Ti6A14V1Zr & -0.126 & -0.089 & -0.126 & -0.008 \\
2000 & Ti6A14V & +0.198 & +0.199 & +0.001 & +0.033 \\
& Ti6A14V1Zr & -0.187 & -0.104 & -0.083 & -0.062 \\
3000 & Ti6Al4V & +0.228 & +0.231 & +0.003 & +0.014 \\
& Ti6A14V1Zr & -0.199 & -0.221 & -0.079 & +0.079 \\
\hline
\end{tabular}

Improvement of corrosion and ion release rates from Tafel curves

From Tafel curves, the corrosion current densities and corrosion rates were obtained (Table 6); also ion release rates were calculated. The new Ti-6Al-4V-1Zr alloy has a very good anticorrosive resistance, being classified as "Perfect Stable" and "Very Stable". The ternary Ti-6Al-4V alloy presented slow higher corrosion rates than quaternary Ti-6Al-4V-1Zr alloy, situated in the "Very Stable" category. ${ }^{27}$

\section{CONCLUSIONS}

The corrosion resistance improvement of the new Ti-6Al-4V-1Zr alloy in comparison with ternary Ti-6Al-4V alloy in Ringer-Brown solution was proved by the more electropositive corrosion potentials, lower passive current densities and better tendency to passivation, resulting from the beneficial influence of $\mathrm{Zr}$. Impedance spectra revealed better protective properties of the passive layer on the surface of the new alloy. 
Table 6. Corrosion current density, corrosion and ion release rates in CarterBrugirard saliva

\begin{tabular}{|c|c|c|c|c|c|}
\hline $\mathrm{pH}$ & Alloy & $\begin{array}{c}\mathrm{i}_{\text {corr }} \\
\left(\mu \mathrm{A} / \mathrm{cm}^{2}\right)\end{array}$ & $\begin{array}{c}\mathrm{V}_{\text {corr }} \\
(\mu \mathrm{m} / \mathrm{yr} .)\end{array}$ & $\begin{array}{l}\text { Resistance } \\
\text { class }\end{array}$ & $\begin{array}{c}\text { Ion release rate } \\
\left(\mathrm{ng} / \mathrm{cm}^{2}\right)\end{array}$ \\
\hline \multirow[t]{2}{*}{2.54} & Ti6Al4V & 0.140 & 1.601 & VS & 162.66 \\
\hline & Ti6Al4V1Zr & 0.092 & 1.054 & VS & 411.89 \\
\hline \multirow[t]{2}{*}{5.52} & Ti6Al4V & 0.135 & 1.534 & VS & 155.85 \\
\hline & Ti6Al4V1Zr & 0.137 & 0.984 & PS & 99.97 \\
\hline \multirow[t]{2}{*}{8.21} & Ti6Al4V & 0.125 & 1.421 & VS & 144.37 \\
\hline & Ti6Al4V1Zr & 0.082 & 0.944 & PS & 95.91 \\
\hline \multirow[t]{2}{*}{8.91} & Ti6Al4V & 0.153 & 1.742 & VS & 176.98 \\
\hline & Ti6Al4V1Zr & 0.090 & 1.028 & VS & 104.46 \\
\hline \multirow[t]{2}{*}{$8.21+\mathrm{NaF}$} & Ti6Al4V & 0.161 & 1.832 & VS & 196.13 \\
\hline & Ti6Al4V1Zr & 0.133 & 1.511 & VS & 153.81 \\
\hline
\end{tabular}

PS - Perfect Stable; VS - Very Stable

In Carter-Brugirard artificial saliva it resulted the same more favorable values of all electrochemical parameters for Ti-6Al$4 \mathrm{~V}-1 \mathrm{Zr}$ alloy. Open circuit potentials tend to more electropositive values, denoting an increase of the passive film thickness. Fluoride ions had a slight negative influence on the corrosion and ion release rates, without to affect the very good stability of the new Ti-6Al$4 \mathrm{~V}-1 \mathrm{Zr}$ alloy.

\section{ACKNOWLEDGMENT}

Financial support from Romanian CNCSIS Program PCCE, project no. 248 is greatly appreciated.

\section{REFERENCES}

1. Milosev, I.; Metikos-Hukovic, M.; Strenhblow, H. H.; Biomaterials 2000, 21, 2103.

2. Manhabosco, T. M.; Muller, I. L.; Santos, C. B.; Quim. Nova 2009, 32, 2263.

3. Almeida Filho, D.; Assis, C. M.; Vercik, L. O.; Guastaldi, A. C.; Quim. Nova 2007, 30, 1129.

4. Braga, N. A.; Ferreira, N. G.; Cairo, C. A. A.; Quim. Nova 2007, 30, 450.

5. Ramires, I.; Guastaldi, A. C.; Quim. Nova 2002, 25, 10.

6. Araujo, J. C.; Sena, L.; Bastos, I. N.; Soares, G. D.; Quim. Nova 2007, 30, 1853.

7. Case, C. P.; Langkamer, V. G.; Jamec, C.; Palmer, M. R.; Kemp, A. J.; Heap, P. F.; Solomon, L.; J. Bone Joint Surg. 1994, 76B, 701.

8. Milosev, I.; Antolic, V.; Minovic, A.; Cor, A.; Herman, S.; Pavlovcic, V.; Campbell, P.; J. Bone Joint Surg. 2000, 82B, 352.

9. Poggie, R. A.; Kovacs, P.; Davidson, J. A.; Mater. Manuf. Proc. 1996, $11,185$.

10. Okazaki, Y.; Nishimura, E.; Nakada, H.; Kobayashi, K.; Biomaterials 2001, 22, 599 .
11. Liu, Y. Z.; Zu, X. T.; Li, C.; Qiu, S. Y.; Huang, X. Q.; Wang, L. M.; Corros. Sci. 2007, 49, 1069.

12. Thomsen, P.; Larsson, C.; Ericson, L. E.; Sennerby, L.; Lausama, J.; Kasemo, B.; J. Mater. Sci. Mater. M. 1997, 8, 653.

13. Saldana, L.; Mendez-Vilas, A.; Jiang, L.; Multigner, M.; GonzalezCarrasco, J. L.; Perez-Prado, M. T.; Gonzalez-Martin, M. L.; Munuera, L.; Vilaboa, N.; Biomaterials 2007, 28, 4343.

14. Oliveira, N. T. C.; Biaggio, S. R.; Rocha-Filho, R. C.; Bochi, N.; J. Braz. Chem. Soc. 2002, 13, 463.

15. Popa, M. V.; Vasilescu, E.; Drob, P.; Vasilescu, C.; Prodana, M.; Rev. Chim. (Buch.) 2008, 59, 618.

16. Cabrini, R. L.; Guglielmotti, M. B.; Almagro, J. K.; Implant Dent. 1993, $2,264$.

17. Prodana, M.; Bojin, D.; Ionita, D.; Popa, M. V.; Vasilescu, E.; Drob, P.; Mol. Cryst. Liq. Cryst. 2008, 486, 133.

18. Guglielmotti, M. B.; Guerrero, C.; Cabrini, R. L.; Acta Odont. Latinoam 1997, 10, 11 .

19. Kulakov, O. B.; Doktorov, A. A.; Diakova, S. V.; Denisov-Nikolskii Yu. I.; Gotz, K. A.; Morfologiia 2005, 127, 52.

20. Geetha, M.; Kamachi Mudali, M.; Gogia, A. K.; Asokamani, R.; Baldev, R.; Corros. Sci. 2004, 46, 877.

21. Assis, S. L.; Costa, I.; Mater. Corros. 2007, 58, 329.

22. Okazaki, Y.; Sethumadhavan, R.; Yoshimasa, I.; Tateishi, T.; Biomaterials 1998, 19, 1197.

23. Pourbaix, M.; Atlas of electrochemical equilibria in aqueous solution, NACE: Houston, 1974

24. Popa, M. V.; Vasilescu, E.; Drob, P.; Vasilescu, C.; Demetrescu, I.; Ionita, D.; J. Mater. Sci. Mater. M. 2008, 19, 1.

25. Mareci, D.; Cretescu, I.; Aelenei, N.; Mirza Rosca, J. C.; Rev. Chim. (Buch.) 2008, 59, 999.

26. Piazza, S. G.; Biundo, L. O.; Romano, M. C.; Sunseri, C.; Di Quatro, F.; Corros. Sci. 1998, 49, 1087.

27. Vasilescu, E.; Drob, P.; Raducanu, D.; Cinca, I.; Mareci, D.; Calderon Moreno, J. M.; Popa, M.; Vasilescu, C.; Mirza Rosca, J.; Corros. Sci. 2009, 51, 2885

28. Tamilselvi, S.; Murugaraj, R.; Rajendran, N.; Mater. Corros. 2007, 58, 113.

29. Black, J.; Biological performance of materials: Fundamentals of biocompatibility, Decker M Inc.: New York, 1992.

30. Reclaru, L.; Meyer, J. M.; Biomaterials 1998, 19, 85.

31. Popa, M. V.; Demetrescu, I.; Suh, S. H.; Vasilescu, E.; Drob, P.; Ionita, D.; Vasilescu, C.; Bioelectrochemistry 2007, 71, 126.

32. Blackwood, D. J.; Chua, A. W. C.; Seah, K. H. W.; Thampuran, R.; Teoh, S. H.; Corros. Sci. 2003, 42, 481

33. Popa, M. V.; Demetrescu, I.; Vasilescu, E.; Drob, P.; Santana Lopez, A.; Mirza-Rosca, J.; Vasilescu, C.; Ionita, D.; Electrochim. Acta 2004, 49, 2113.

34. Popa, M. V.; Vasilescu, E.; Drob, P.; Mareci, D.; Calderon Moreno, J. M.; Ivanescu, S.; Vasilescu, C.; Mirza Rosca, J. C.; Mater. Corros. 2009, $60,949$.

35. Popa, M. V.; Demetrescu, I.; Vasilescu, E.; Drob, P.; Ionita, D.; Vasilescu, C.; Rev. Roum. Chim. 2005, 50, 399. 